熱水性フジツボ類の進化生態学的研究：

深海熱水動物群集の多様性創出・維持機構の解明に向けて

Evolutionary ecology of hydrothermal vent barnacles:

\title{
Toward an understanding of the mechanisms underlying the biodiversity of deep-sea hydrothermal vent communities
}

\author{
頼末武史 ${ }^{1,2 *}$ \\ 1) 兵庫県立大学 自然・環境科学研究所 \\ 2）兵庫県立人と自然の博物館， $=669-1546$ 兵庫県三田市弥生が丘 6
}

Takefumi YORISUE

1) University of Hyogo

2) Museum of Nature and Human Activities, Hyogo,6 Yayoigaoka, Sanda, Hyogo 669-1546, Japan

\begin{abstract}
Since the discovery of deep-sea hydrothermal vent communities in 1977, researchers have made efforts to understand the mechanisms underlying the biodiversity of these communities. "Biodiversity" is hierarchical in nature, ranging from genetic to ecosystem levels and local to regional scales, and encompassing genetic, species, ecosystem, and landscape diversity. A previous paper suggested that interactions between local and regional ecological processes in hydrothermal vent ecosystems could be understood through a metacommunity framework. As a first step toward understanding the complex interactions in these ecosystems, summarizing evolutionary-ecology studies conducted at different hierarchical levels for each vent taxon could be useful. Barnacles are suitable model species for studying evolutionary ecology at various spatiotemporal scales because of the good availability of fossil records, and because of their wide distribution and high potential for laboratory/field-based experiments using both larvae and adults. In this paper, studies on hydrothermal vent barnacles at each hierarchical level of biodiversity are reviewed.
\end{abstract}

Key Words: hydrothermal vent, barnacle, biodiversity, evolutionary ecology

\section{1.はじめに}

深海熱水噴出域（以下，熱水域）には化学合成細菌や古 細菌を一次生産者とする化学合成生態系が発達し, 一般の 深海底と比較して圧倒的に高いバイオマスを有する深海熱 水動物群集（以下，熱水動物群集）が形成されることがよ く知られている（Van Dover 2000, Kojima 2002, Mullineaux 2014)。このような熱水動物群集は 1977 年にガラ パゴス沖で初めて発見されて以来（Corliss 1979），世界各 地のプレート境界で発見が相次いでいる（Beaulieu et al. 2015).これまでに $200 \mathrm{~m}$ 以深の熱水域が 665 箇所発見さ れており（InterRidge Vents Database Ver 3.4: http://vents-data. interridge.org/ventfields_list_all, 2020 年 7 月 27 日にアクセ

Received 18 May 2020 Accepted 11 August 2020

* Corresponding author

E-mail: yorisue@hitohaku.jp
ス)，未発見の熱水域は 900 程度であるとの推定（Beaulieu et al. 2015）や，さらにその数倍あるとの見方もある（Baker et al. 2016). 熱水動物群集の構成種はほとんどが熱水固有 種であり,「世界各地の深海底に飛び石状に分布する環境 において, 熱水動物群集がどのように形成・維持されてい るのか」という問いは，その発見以来多くの研究者を魅了 してきた

一般に生物多様性には階層性の概念がある。すなわち, 種内の遺伝子多型を考慮した“遺伝的多様性”，構成種の 変異性を考慮した“種の多様性”, 生態系の違いを考慮し た“生態系の多様性”, 生態系の集まりを対象とした“景 観の多様性”である。そしてこれらの多様性は階層間で複 雑に相互依存していると考えられる。例えば近年，生物進 化が生物間相互作用に影響して個体群動態などの生態過程 を変化させ，さらにその変化が生物進化過程に影響すると いう eco-evolutionary dynamicsに関する報告が増えてきて いる (Toju et al. 2017, Brunner et al. 2018, Hendry 2019). 熱水動物群集の形成機構を議論する上でも，このような階 
Examples of abiotic factors affecting vent fauna
Hierarchal structure

of biodiversity

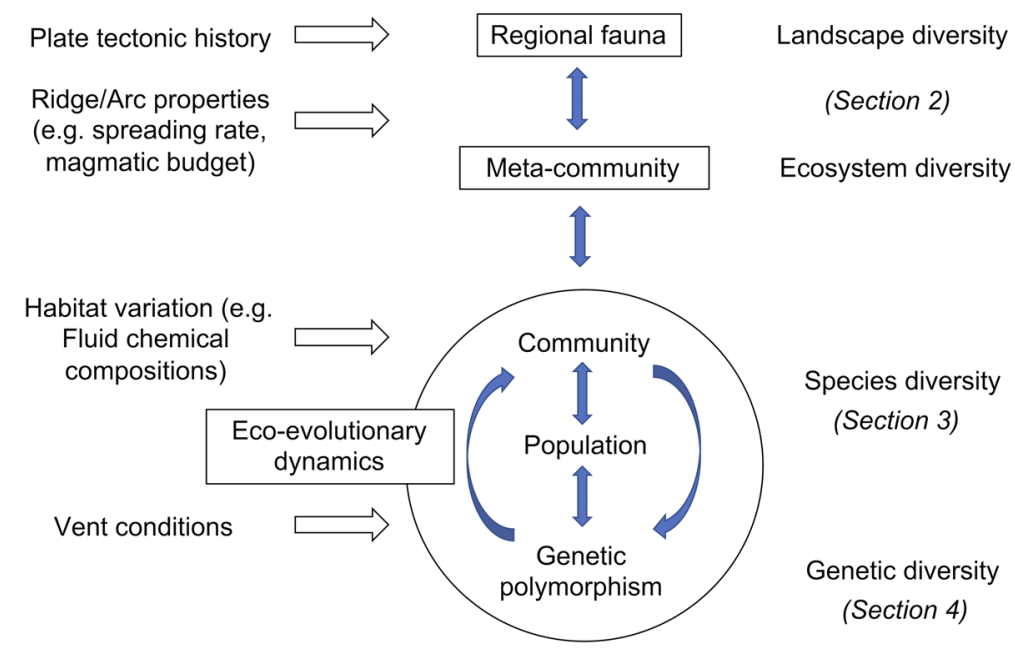

Fig. 1. Factors affecting hydrothermal vent fauna at various spatiotemporal scales, and the corresponding hierarchal levels of biodiversity. Filled arrows indicate putative interactions. Related sections of this paper are indicated below each hierarchal level of biodiversity. This figure was modified from Figure 4 of Mullineaux et al. (2018) (Copyright (C 2018 Mullineaux, Metaxas, Beaulieu, Bright, Gollner, Grupe, Herrera, Kellner, Levin, Mitarai, Neubert, Thurnherr, Tunnicliffe, Watanabe and Won).

層性と階層間の相互関係を考慮する必要があるだろう。実 際に近年, メタ群集の概念を取り入れ, プレート運動一地 域ごとの地質的特性-熱水域・熱水サイトレベルでの熱水 活動の動態, に対応させて生態過程を分類することで階層 性を整理し, 熱水動物群集の複雑な形成機構を解明してい くことが提案されている (Mullineaux et al. 2018, Fig. 1). また全球スケールにおいては, 出現分類群データの解析に 基づき, 熱水域を 11 の生物地理区分に分類することが提 案されている (Rogers et al. 2012).このような生物地理区 分の形成は, 1-100 Ma 以前からの地史・熱水活動史と大 きく関わっていると考えられる（Bachraty et al. 2009）。 ま た, 種内の遺伝的多様性データと幼生分散シミュレーショ ン分析によって, 多数の生物種で集団間の連結性が担保さ れうる熱水域を選定し, 保護区を設計する試みも進められ ている（Mitarai et al. 2016）。この区分では，生物の世代時 間スケールの生態過程が反映されていると考えられる。 ま た各熱水域での群集生態学的研究 (e.g. Bergquist et al. 2007, Portal et al. 2016, Husson et al. 2017, Lelièvre et al. 2019）や，個々の種の遺伝的多様性や集団遺伝解析に関し ても多くの研究が報告されている（e.g. Vrijenhoek 1997, 2010, Teixeira et al. 2013, Roteman et al. 2016).このよう に, 熱水域での生物多様性が創出されるメカニズムに関し て, 様々な階層の研究がなされてきた. 一方で階層間の相 互関係に関する研究は乏しいのが現状である.

熱水域における複雑な階層構造を考慮した生物多様性創 出機構を解明する足がかりとして, 個々の分類群に着目し た階層間の相互作用に関する研究アプローチが有効であろ う. 例えばフジツボ類（ここでは完胸上目の蔓脚類を指す） は成体・幼生の採集及び大気圧下での飼育が比較的容易で
あり（渡部 2003，Watanabe et al. 2004，2006， Miyake et al 2007, Yorisue et al. 2013), 野外での実験生態学的アプロー チが適応出来うること（松村・野方 2006）から，生理特性 や生活史特性, 種間相互作用等を研究する上で有用であ る. また，大西洋を除く世界各地の熱水域に分布している こと（山口 2006, Herrera et al. 2015）も, モデル生物とし ての有用性を高めている。加えて, フジッボ類は熱水域以 外の深海を含め, 多様な海洋環境に生息していることから, 比較研究によって熱水域への適応機構を議論しやすいとい う利点もある（渡部 2003，Yorisue 2018）。また，地質学的 時間スケールの進化史に関する研究においては，化石記録 が利用できるという点も大きな利点である（土田ら 2008， Watanabe et al. 2018, Gale et al. 2020). 無論, 分類群毎に異 なる進化史を持っていることもあり（Vrijenhoek 1997， 2010, 渡部・小島 2009), フジッボ類の研究だけで熱水動 物群集の進化史や多様化機構が全て解明されるわけではな い。しかし上記に挙げた理由により，その足がかりを掴む 上で, フジッボ類は有用な研究対象生物であると言えるだ ろう。そこで本本稿では，熱水性フジッボ類を対象とした 様々な階層での研究をレビューし, 今後の展開について議 論する.

\section{2. 熱水性フジツボ類の進化史}

これまでに多くの熱水性動物について，遺伝情報に基づ いた進化史が研究されてきた（Vrijenhoek 1997，2010，渡 部・小島 2009, 小島ら 2009). 熱水性フジッボ類の進化 過程に関しては当初, 形態形質に基づいた分類学的アプ ローチによって議論がされてきた（Newman \& Yamaguchi 
1995, 山口 2006, 2008). しかしその後の分子系統解析に より，熱水性フジッボ類に関して分類体系が系統関係を反 映していない例もわかってきた（Pérez-Losada et al. 2008）. 2000 年代以降, 熱水性フジツボ類において DNA 多型解析 が報告されるようになり, 系統地理学的解析に基づいた進 化史が議論されている. 本章では, 種レベルの進化史とそ れぞれの種内の集団史に分け，これまでの研究事例をまと める.

\section{2-1. 熱水性フジツボ類の分布}

これまでにアカツキミョウガガイ科 Neolepadidae, ネッ スイハナカゴ科 Neoverrucidae, Probathylepadidae, ムヘイレ パス科 Neobrachylepadidae, アカツキフジツボ科 Chionelasmatidae に属する熱水性フジツボ類が報告されており（Fig. 2; Newman et al. 2006, 山口 2006, Ren \& Sha 2015), 近年も新 種記載が続いている（例えば Ren \& Sha 2015, Chan \& Chang 2018, Watanabe et al. 2018, Chan et al. 2019). 大西 洋中央海嶺と北極域の熱水域からはフジッボ類の報告はな いが, 特に南大西洋は調査が不十分であり, 今後熱水性フ ジツボ類の分布が確認されるかもしれない.

\section{2-2．種レベルでの熱水性フジツボ類の進化史}

熱水性フジッボ類の進化史については, 既に分子系統地 理学的解析に基づいて詳しく検討されている（Herrera et al. 2015). 以下に, Herrera et al.（2015）における議論を 中心に，熱水性フジツボ類の進化史についてまとめたい.

従来の分子系統解析では, 熱水性フジツボ類は単系統群 を形成することが報告されてきたが (Pérez-Losada et al. 2008, Linse et al. 2013), Herrera et al. (2015) のより広範な タクソンサンプリングに基づく解析によって, フジツボ類 は進化の過程で少なくとも 2 回独立に熱水域に進出した （クレード A及びB）ことが示されている. クレード A に
はアカツキミョウガガイ科，ネッスイハナカゴ科，ムへイ レパス科が含まれ, 深海性の祖先種が熱水域に進出し, 中 新世以降に多様化したと考えられている（Linse et al. 2013, Herrera et al. 2015).これは, 他の熱水性生物や深海生物と 同様, $\mathrm{K}-\mathrm{Pg}$ 境界（約 6500 万年前の中生代と新生代の境） の大量絶滅イベント後の多様化（Little \& Vrijenhoek 2003, Smith \& Stockley 2005, Strugnell et al. 2008）を示している. さらにクレード $\mathrm{A}$ の起源は西太平洋にあり, 太平洋南極海 嶺（Pacific-Antarctic Ridge）を経由して東太平洋に渡り，後 期中新世にはドレーク海峡（南アメリカ大陸南端と南極半 島の間にある海峡）の形成等に伴い，南極東スコシア海嶺 (East Scotia Ridge）とサウスサンドイッチ弧（S. Sandwich Arc）を経由してインド洋に到達したと考えられている (Herrera et al. 2015).この仮説は, その後のアカツキミョウ ガガイ科を対象とした化石記録・分子系統理的解析によっ ても支持されている（Watanabe et al. 2018）. また，ハツシ マレパス Ashinkaikepas seepiophila は湧水域にも分布する唯 一の種で, 熱水固有の祖先種がメタン涌水域に進出したこ とを示している（Herrera et al. 2015）。この点は鯨骨・沈木 や湧水域から熱水環境に進出したとされる他の分類群とは 異なる（例えばLorion et al. 2013）点で興味深い.クレード B にはアカツキフジツボ科のみが含まれ，このグループの 進化史を解明するには，近縁種を含めたより詳細な系統解 析を実施する必要がある。

\section{2-3. 熱水性フジツボ類の集団史}

北西太平洋に位置する沖縄卜ラフと伊豆一小笠原弧の熱 水域から採集されたネッスイハナカゴ Neoverruca intermedia を対象に，ミトコンドリア DNA COI 領域の塩基配列デー タに基づいた集団史が検討されている（Watanabe et al. 2005).この研究では, 互いに 1,500-2,000 km 程度離れた 沖縄トラフと伊豆一小笠原弧の集団は遺伝的に分化してい

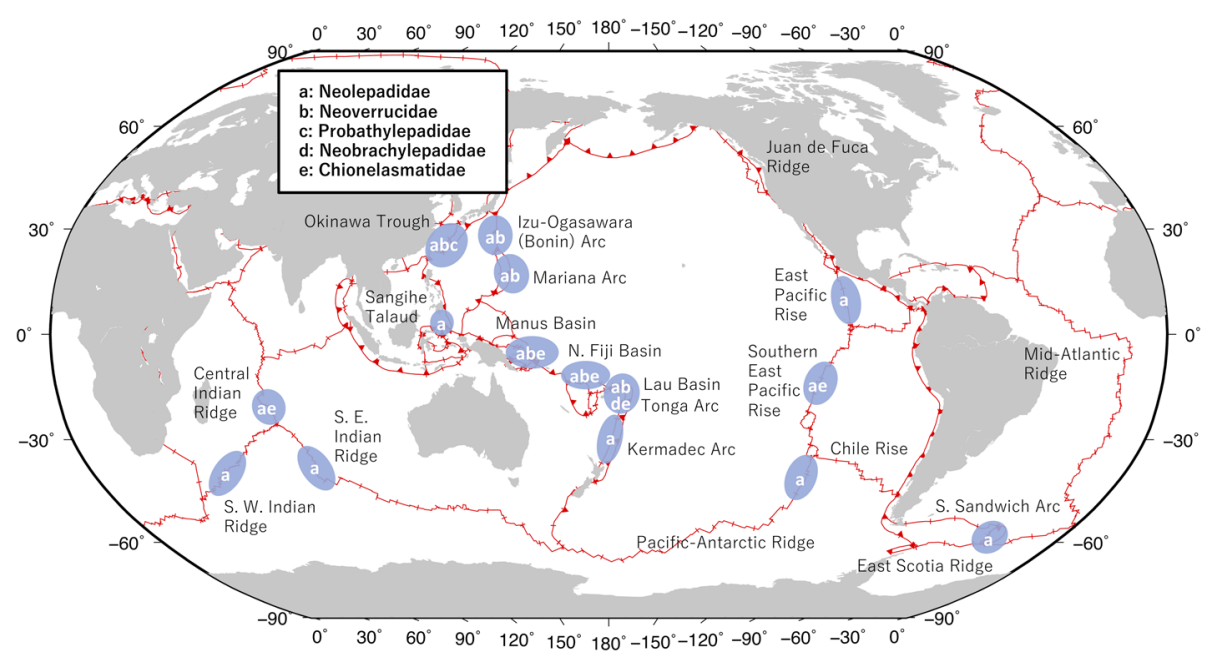

Fig. 2. Global distribution map of hydrothermal vent barnacles. Information on the distribution was obtained from Yamaguchi (2006), Tsuchida et al. (2008), Herrera et al. (2015), Ren \& Sha (2015), and Chan et al. (2019). 
ることを示しており, 沖縄トラフの集団が伊豆一小笠原弧 の集団の起源であると推定している．またこれらの集団は 熱水活動の消長に伴うと考えられる集団サイズの縮小（ボ トルネック）とその後の急激な拡大を経験していることが 示唆されている (Watanabe et al. 2005).

南西太平洋のマヌス海盆では, マヌスアケボノフジッボ Eochionelasmus ohtai manusensis と Vulcanolepas cf. parensis を対象に，COI 領域の塩基配列データに基づいた集団史が 検討されている (Plouviez et al. 2013)。これらの種では〜 $47 \mathrm{~km}$ の範囲におけるサンプリングサイト間では遺伝的な 分化は検出されていない (Plouviez et al. 2013). マヌスア ケボノフジッボはボトルネックを経験しているが，V.cf. parensis は集団サイズが安定して維持されてきたことも示 唆されている (Plouviez et al. 2013).V. c cf. parensis は熱水 への依存度が低い（熱水域の縁辺部に分布している（Collins et al. 2012)）ことから，熱水活動の変動に対する影響を受 けにくいことを示しているのかもしれない（Plouviez et al. 2013).

\section{3. 環境勾配に沿った熱水性フジツボ類の 分布パターンの成因}

本章では熱水域内でのフジッボ類の多種共存機構とし て，同一の熱水域に生息するフジッボ類種間における生 理・生態学的な比較研究を紹介する. 分散期幼生, 着生期 幼生，成体と様々な発生段階を対象とした研究が報告され ているため, 最初に熱水性フジツボ類の生活史に関して簡 潔に述べてから，具体的な研究例を紹介する.

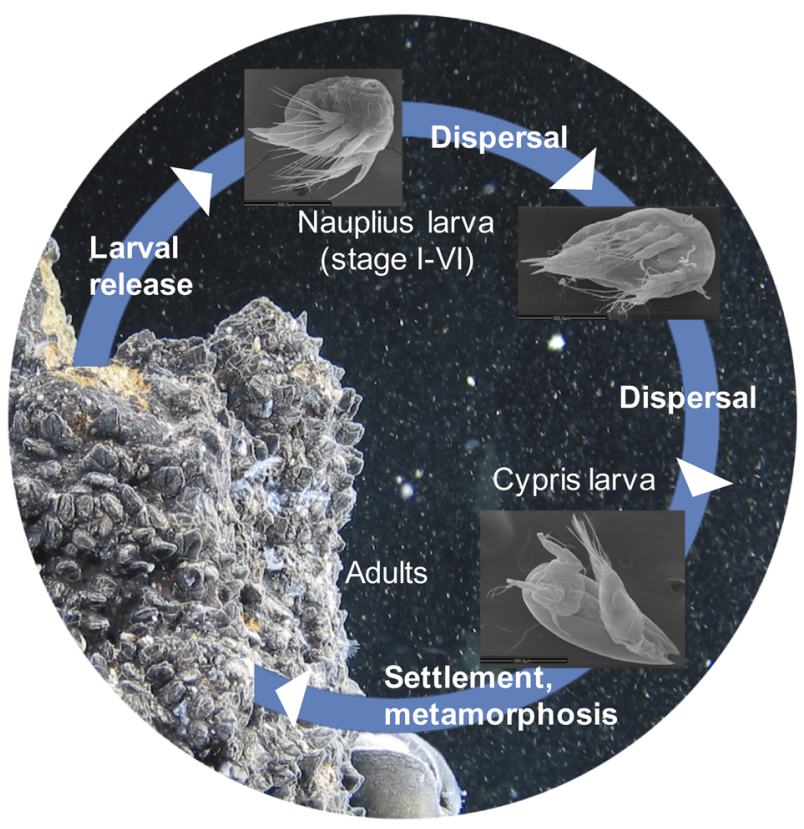

Fig. 3. Life cycle of hydrothermal vent barnacles. A photograph of Neoverruca intermedia adults and scanning electron microscopy images of the larvae are shown.

\section{3-1. 熱水性フジツボ類の生活史}

熱水性フジツボ類は雌雄同体で，近隣の個体と交尾を行 う。受精卵は外套腔で発生し，ノープリウス幼生となって 孵出する (Fig. 3)。ノープリウス幼生は卵黄栄養性で (Tunnicliffe \& Southward 2004, Watanabe et al. 2004, Yorisue et al. 2013), 多くの浅海種でみられるようなプランク トン食性の種は確認されていない。ノープリウス幼生は第 1 期〜第 6 期まであり，遊泳しながら海洋中を分散する（Fig 3). 飼育下でのノープリウス幼生期間は 100 日を超えるこ ともあり（Watanabe et al. 2004），一般的な浅海種（例えば クロフジッボ類 Tetraclita spp. では 2 週間程度; Chan 2003）と比較して非常に長い。キプリス幼生は着生場所の 探索に特化した幼生であり，一対の特殊化した第一触角を 有する (Fig. 4)。第一触角の先端には付着器官と呼ばれる 釣鐘様の構造があり，付着盤 attachment disc（Fig. 4）とい
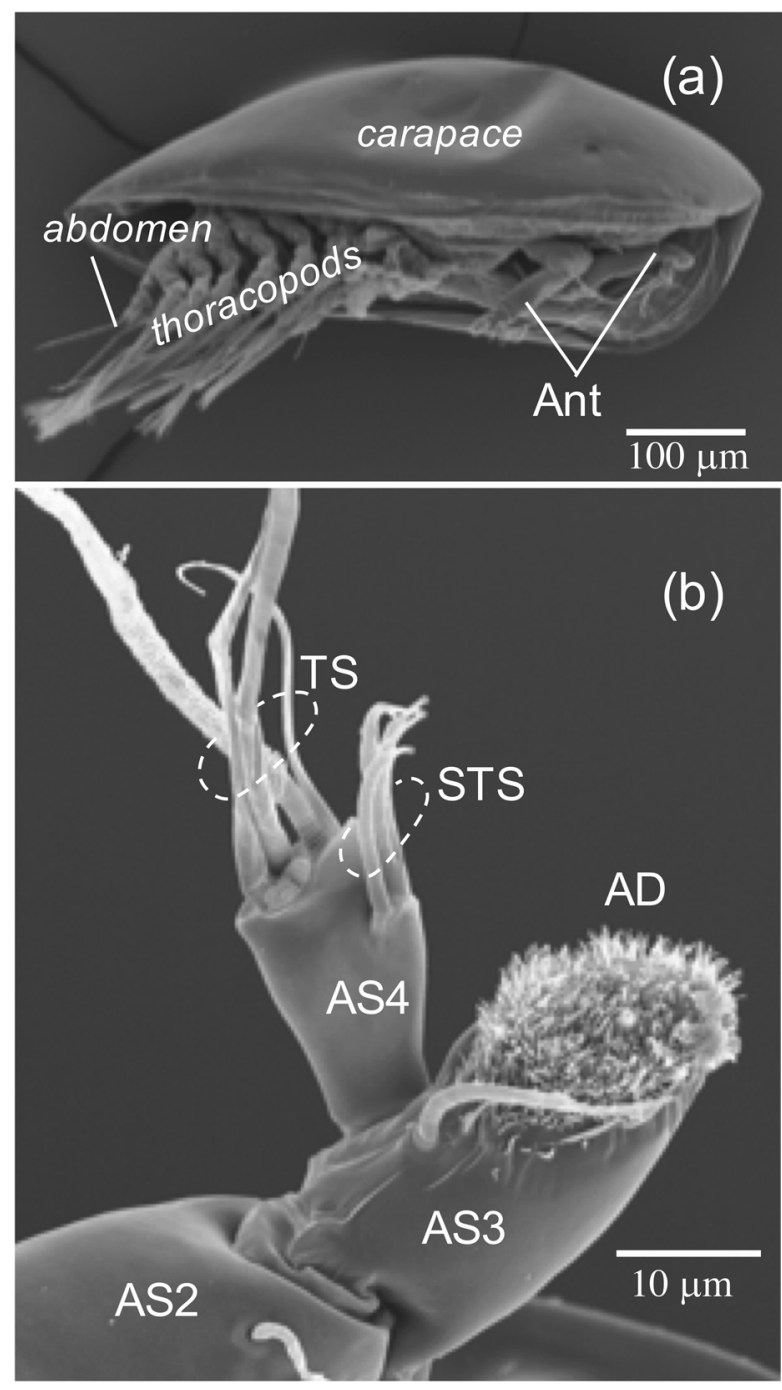

Fig. 4. Scanning electron microscopy images of cypris larvae of Neoverruca intermedia. (a) Lateral overview and (b) antennular sensory organs. AD, attachment disc; AS2 -4 , antennular segments 2-4; Ant, antennules; STS, subterminal setae on AS4; TS, terminal setae on AS4. 


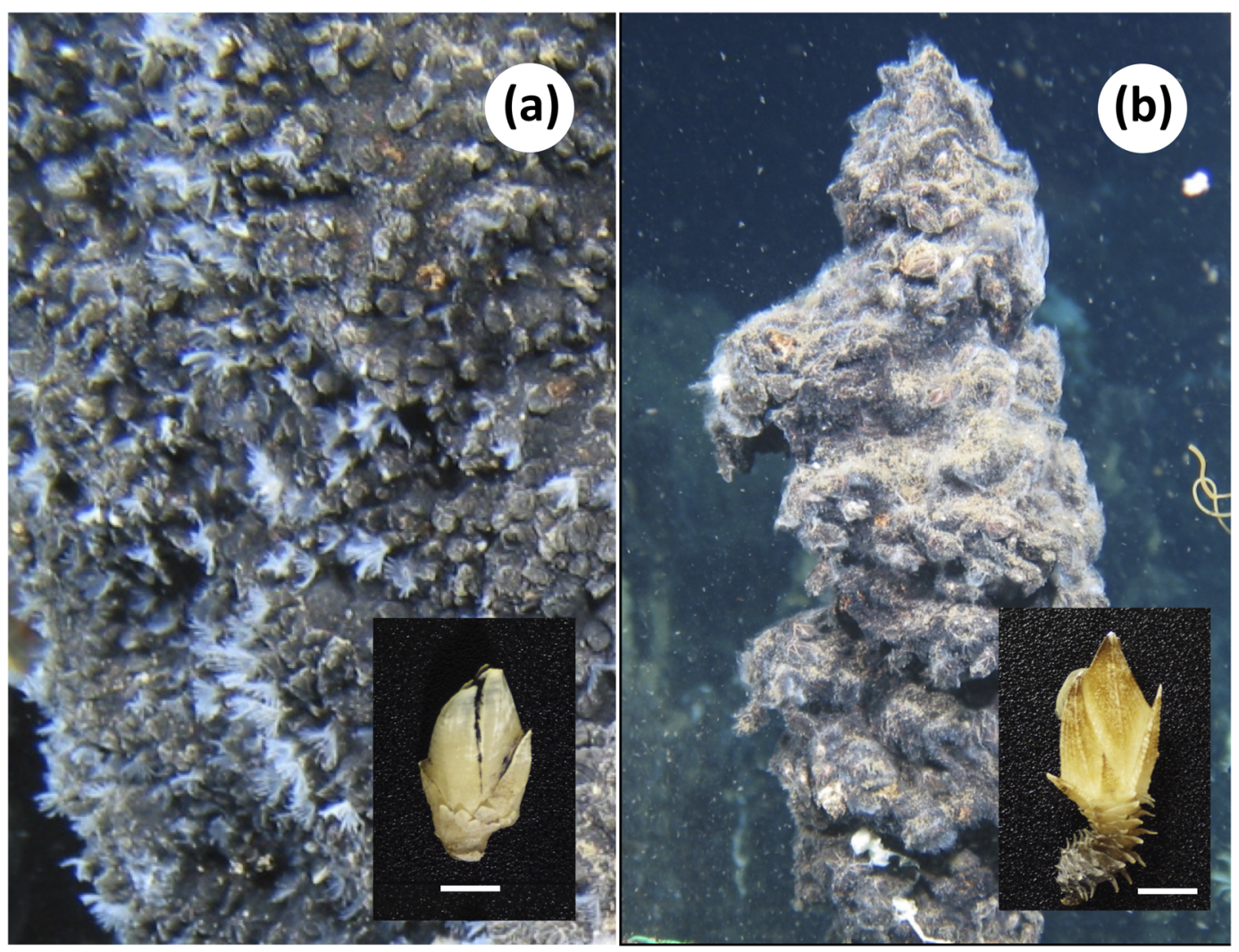

Fig. 5. Hydrothermal vent barnacles at the Myojin Knoll in the Izu-Ogasawara Arc. (a) Neoverruca intermedia living near active vents. (b) Ashinkailepas seepiophila inhabiting a dead chimney. Bars indicate $5 \mathrm{~mm}$.

う盤状の表面を足の裏のようにして基盤表面に押し当てな がら歩く行動をする。これは”探索行動”と呼ばれ，第一 触角に備わった刺毛によって基盤表面の物理化学性状を探 りながら好適な着生場所を探っている（Lagersson \& Høeg 2002, 松 村 2006, Bielecki et al. 2009, Maruzzo et al. 2011). 着生した個体は摂慨しながら成体へと発生・成長 を進めていく（Fig. 3).

\section{3-2. 熱水域における熱水性フジツボ類の分布パターン}

熱水噴出域の特徴として, 潮間帯域で知られるような急 激な環境勾配の存在が挙げられる. 噴出される熱水の温度 は数百 ${ }^{\circ} \mathrm{C}$ 達することもあるが, 周囲の海水で泠やされる ことにより, 噴出孔から数 $\mathrm{m}$ 離れれば $4{ }^{\circ} \mathrm{C}$ 程度まで水温 が低下する. また水温の低下に伴い, 化学環境も同様に急 激な勾配を示す（Mullineaux 2014）。熱水近傍にはエラゴ カイ科多毛類やオ八ラエビ類のように, 高温環境に適応し た動物も生息している（Chevaldonné et al. 2000, Ravaux et al. 2019). 伊豆一小笠原弧の明神海丘では, ネッスイハナカゴ とハッシマレパスの 2 種のフジッボ類が分布している (Fig. 5). 前述した通り, ハツシマレパスはメタン湧水域 での生息も確認されている。明神海丘において，これら 2 種はそれぞれ, 熱水噴出孔の近傍と縁辺に分布している (Fig. 5).ネッスイハナカゴとハッシマレパスの分布帯の 水温はそれぞれ概ね $10-20^{\circ} \mathrm{C}$ 程度, $4^{\circ} \mathrm{C}$ 程度である. 以下,
本章ではこれら 2 種を対象とした研究を紹介し, その分布 パターンの成因について検討する。

\section{3-3. 水温とノープリウス幼生期間の関係}

既に述べた通り, 両種のノープリウス幼生は卵黄栄養性 であり, 摂慨しない，室内飼育下において，ネッスイハナ カゴの浮遊幼生期間（ノープリウス幼生がキプリス幼生に 変態するまでの期間）は $4{ }^{\circ} \mathrm{C} て ゙ ~ 100$ 日程度（Watanabe et al. 2004)，10두 50 日程度である（Watanabe et al. 2006）。一

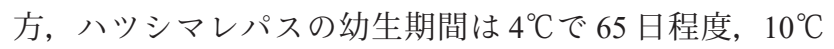
で 54 日程度（Yorisue et al. 2013）である. 両種において, $10^{\circ} \mathrm{C}$ で飼育した際の幼生期間は $4^{\circ} \mathrm{C}$ 環境下と比較して短縮 されており, 高温飼育下では代謝が高まり, 発生が促進さ れることがその一因であると考えられる。しかし，キプリ 又幼生直前のノープリウス第 6 期に着目し, 温度上昇に対 する応答性を温度係数 $\left(\mathrm{Q}_{10}\right)$ で比較すると, ネッスイハ ナカゴの方が圧倒的に高く（Yorisue et al. 2013），ネッスイ 八ナカゴのノープリウス幼生はハツシマレパスのノープリ ウス幼生より高い高温応答性を示しており, 高温環境下で より迅速にキプリス幼生へ変態することが示唆された (Watanabe et al. 2006, Yorisue et al. 2013). キプリス幼生へ の変態が促進されるということは, 着生までの時間が短縮 されることを意味する．高温帯に分布するネッスイハナカ ゴは, 熱水由来の温度刺激によって好適な生息環境に迅速 
に着生できるように適応したのかもしれない。

\section{3-4. 着生誘起フェロモンの研究}

一般にフジツボ類は, Settlement Inducing Protein Complex （SIPC）と呼ばれるタンパク質性のフェロモンを分泌するこ とで, 幼生の着生を誘起していることが知られている（Matsumura et al. 1998, 松村ら 2002, Clare 2010). SIPCには不 完全ながら種特異性があり, 幼生は, 同種から分泌される SIPC によって強く着生が誘起される（Dreanno et al. 2007）. また浅海種の遺伝子解析から, SIPC には種間で変異が蓄積 した領域が存在し, 種特異性と大きく関わっていることが 示唆されている (Yorisue et al. 2012b). ネッスイハナカゴ では浅海種と比較して SIPC の発現が高いことが, 免疫学 的手法により示唆されている (松村ら, 未発表). 一般的 な浅海性の種では, キプリス幼生はキプリス眼と呼ばれる 一対の複眼を有し, 成体個体に由来する視覚シグナルも着 生場所の選択に重要な役割を果たしていることがわかって きている（Matsumura \& Qian 2014, 松村 2014）。しかし, ネッスイハナカゴとハツシマレパスのキプリス幼生はキプ リス眼を欠いており（Watanabe et al. 2004, Yorisue et al. 2013), 着生場所の探索に視覚シグナルは関わっていない と考えられる.そのため太陽光が届かない深海熱水環境で は, フジツボ類の着生場所選択において SIPCを介した化 学コミュニケーションがより重要な役割を果たしているの かもしれない.このような仮説を検証するために, 明神海 丘ではネッスイハナカゴを対象とした長期加入実験の試み も進められてきた（松村・野方 2006）. 熱水性フジッボ類 において,「浅海種と比較して SIPC が生息場所選択によ り重要な役割を果たしている」，という仮説については今 後の室内外でのさらなる実験検証が必要である.

\section{3-5. キプリス幼生の付着器官の形態}

ネッスイハナカゴとハッシマレパスでは, 走査型電子顕 微鏡を用いたキプリス幼生の付着器官の形態観察が行われ ている (Yorisue et al. 2016). キプリス幼生の付着器官にお いては，それぞれの種が生息環境において探索行動を行う ためにしばしば特徴的な形態形質を進化させていることが 知られている（Moyse et al. 1995, Blomsterberg et al. 2004, Brickner \& Hoeg 2010, Chen et al. 2013, Ai-Yahya et al. 2016, Yu et al. 2020). ネッスイハナカゴとハッシマレパス のキプリス幼生の付着器官は互いによく類似した構造をし ており, 両種の間で探索行動に違いがあるという形態学的 な証拠は得られていない（Yorisue et al. 2016）。一方で両種 共に付着盤の周囲にある velum/skirt と呼ばれる構造が著し く退化しているという形質をはじめ，他の種では見られな い形態形質がいくつか観察されている（Yorisue et al. 2016）. Velum/skirtの機能は未解明であり, 熱水性フジツボ類で見 られる形態的特徵が熱水域での探索行動を行うための適応 であるかは不明である。浅海種のタテジマフジッボ
Amphibalanus amphitriteでは探索行動時における付着器官 上の各刺毛の挙動解析も実施されており (Marruzo et al. 2010), 今後の velum/skirt の挙動解析や機能推定も期待さ れる.

\section{3-6. 成体の食性}

ネッスイハナカゴとハッシマレパスでは, 炭素・窒素安 定同位体比解析を用いた成体の餌資源推定が行われている (Yorisue et al. 2012a). その結果, ネッスイハナカゴでは噴 出口近傍に分布する化学合成細菌に依存しているのに対 し，ハツシマレパスでは光合成産物にも依存していること が示唆されている (Yorisue et al. 2012a).さらに, 両種の 食性に対応した口器の形態的特徴も確認されている（渡部 ら未発表)。このような明確な成体の食性の違いにより， それぞれの餌資源が豊富な場所に着生した個体の生存率が 高まり, 分布が規定されていることが示唆される.

\section{3-7. 3 章のまとめ}

一連の研究から, 以下の 3 点がネッスイハナカゴとハッ シマレパスの分布の違いに貢献していることが示唆され る；1. ネッスイハナカゴのノープリウス幼生はハツシマレ パスよりも高温応答性が高く, 熱水由来の熱水近傍に迅速 に着底する，2. 種特異性のある着生フェロモンによる化学 コミュニケーションにより同種個体の近傍に着生する, 3. 成体の食性の違いにより，それぞれの餌資源が豊富な場 所に着生した個体の生存率が高まる。また最近, 硫化水素 の無毒化に関わっているとされるタウリン関連化合物の含 有量が両種で差がないことが報告されている（Koito et al. 2018).しかし温度や硫化水素濃度などの環境ストレス耐 性や捕食圧などの種間関係に着目した研究報告はまだまだ 少ないのが現状であり, 今後の研究進展が期待される。熱 水域内でのフジツボ類の異なる分布パターンは, 他の種・ 地域でも見つかっている（Collins et al. 2012, March et al. 2012).これらの種での分布パターンの成因については, 今後の研究が必要である.

\section{4. 熱水性フジツボ類の遺伝的多様性}

これまでいくつかの熱水性フジツボ類の種を対象とし て，中立 DNA マーカーに基づく遺伝的多様性および集団 遺伝解析が報告されている。一般に, 基盤種の遺伝的多様 性（Whitham et al. 2006）やキーストーン遺伝子（Skovmand et al. 2018）の変異は群集や生態系レベルの過程にま で影響を及ぼしうる。フジツボ類も基盤種としての機能を 有することが知られ（Glynn 1965, Lohse 1993），その遺伝 的多様性を把握することは群集や生態系レベルの事象を理 解する上でも重要である．以下に，熱水性フジッボ類の種 を対象とした遺伝的多様性に関する研究の現状をまとめ る. 


\section{4-1. 中立 DNA マーカーを用いた研究}

ネッスイハナカゴ, マヌスアケボノフジッボ, Vulcanolepas cf. parensis では，ミトコンドリア DNA COI 領域の 中立变異に基づいた遺伝的集団構造解析が実施されている (Watanabe et al. 2005, Plouviez et al. 2013).ネッスイハナ カゴの幼生は主に底層流を使って分散することが示唆され ており (Yorisue et al. 2013), 沖縄トラフ Okinawa Trough と伊豆-小笠原孤 Izu-Ogasawara Arc の間に存在する琉球弧 が両地域間の分散障壁になっている可能性がある（Watanabe et al. 2005). また仮に表層まで鉛直移動したとして も，幼生の高水温耐性が低いために暖流（黒潮）の影響で 死滅してしまうことが示唆されている（Watanabe et al. 2005，2006）。また，熱水活動の消長に伴うと考えられる ボトルネック効果も検出されていることから（Watanabe et al. 2005, Plouviez et al. 2013), 熱水性フジッボ類の進化の過 程において遺伝的浮動が重要な役割を果たしてきたことが 強く示唆される。これは他の熱水性生物にも当てはまる (Jollivet et al. 1999, Vrijenhoek 2010). マヌス/フィジー海 盆産とラウ海盆産のフィジーアケボノフジツボ E. ohtai ohtai では発生段階での周殼基部の付随小殼板の配列に地 域差が見られており（Yamaguchi \& Newman 1997）, 遺伝 的浮動の影響を反映しているのかもしれない。また，ネッ スイハナカゴではマイクロサテライトマーカーが開発され ていることから（Nakajima et al. 2014），それぞれの地域内 での詳細な遺伝子流動パターンや遺伝的地理構造の解明が 期待されている.

\section{4-2. 非中立 DNA マーカーを用いた研究}

潮間帯のフジツボ類では, 環境勾配に沿った適応遺伝子 の遺伝子型頻度の勾配が検出されており（Holm \& Bourget 1994, Schmidt \& Rand 1999, Schmidt et al. 2000, Veliz et al. 2004, Flight \& Rand 2012), 平衡選択によって遺伝子型頻 度の勾配が維持されている（Schmidt et al. 2000）。熱水性 の種に関しても, 環境勾配やストレス強度に応じた適応遺 伝子の種内多型が存在すると想定されるが，こうした非中 立DNA マーカーはまだ見つかっていない, 今後, 群集構 造などにも影響を及ぼすようなキーストーン遺伝子 (Skovmand et al. 2018）の発見も期待される.

\section{5. 今後の展望}

本稿では熱水性フジツボ類に関する様々な時空間スケー ルを対象とした研究事例をまとめた．未解明な点も多く残さ れているとは言え, プレート運動等の地史と対応した進化 史, 熱水活動の消長と集団進化の関連, 熱水域内での多種 共存機構など，様々な階層スケールでの事象が解明されつ つある. 今後の熱水性動物・熱水動物群集を対象とした異 なる階層間の相互関係の解明に向けた研究においても, フジ ツボ類が有用な研究対象生物の一つとなると考えられる.
1977 年における熱水動物群集の発見から 40 年以上が経 過したが，これまでに発見された熱水動物群集の数は全体 の半分にも満たないという (Beaulieu et al. 2015, Baker et al. 2016). 近い将来まだ見ぬ熱水動物群集が多数発見さ れ，新たな研究課題も次々に生まれてくるだろう。熱水動 物群集の研究においては, アクセスの困難さによる研究手 法や調査頻度の制限が律速となり, 研究の進展が抑制され てきた一面もあるだろう。一方で次世代シーケンサーによ る技術革新により，ゲノム解析を中心とした研究が格段に 進んでいる（例えば Goodwin et al. 2016, Wachi et al. 2018, 井口ら 2019, Garlapati et al. 2019)。すでに熱水動物群集 の研究にも取り入れられており（例えばXu et al. 2017, Sun et al. 2020), 遺伝的集団構造や環境適応の分子基盤の 解明が進んでいくと期待される. 最近では, メ夕群集の概 念を使った階層間の相互関係を解明しようとする試みもあ る(Mullineaux et al. 2018)。このような取り組みにおい て, 最新技術も取り入れた研究が熱水生態系に関する異な る階層間の相互関係を明らかにしていくと期待される。ま た熱水域に関する生態系・景観の多様性という広域スケー ルを対象とした研究では, 熱水鉱床開発に伴う周辺海域へ の環境影響も懸念されており（Boschen et al. 2013，Van Dover 2014, 2018, Levin et al. 2016, Jones et al. 2018), 今後 の研究進展が期待される. 熱水性動物の幼生は分散過程で 熱水噴出域以外の生態系を利用している（Adams 2012, Yahagi et al. 2017）ため, “幼生”は異なる生態系との繋が りを理解する上で重要なキーワードとなるだろう（渡部・ 加戸 2005, 頼末・渡部 2010, 矢萩他 2019).

前段落で技術革新に伴う研究進展の期待について述べた が, 従来の研究手法の有用性を否定するわけではない. 生 命現象の摂理を追求する上で重要なことは，生物の“した たかさ”や“奥深さ”に対する興味を各々の研究者が持ち 続け, 状況に応じて研究手法を選択して上手く利用するこ とである。また熱水域での生物多様性創出機構を解明する には，熱水域以外での研究も重要になってくる，矢萩ら （2019）でも強調されているように，多様な背景を持つ研 究者（その卵となる学生も含む）が協力し, 熱水域やベン トスを対象とした新たな領域の研究が展開されていくこと を期待したい.

謝辞: 本論文は著者の 2019 年日本ベントス学会奨励賞受賞記 念論文として執筆しました，著者のこれまでの研究を支援してく ださった, 小島茂明教授（東京大学・大気海洋研究所）, 渡部裕 美博士 (海洋研究開発機構), 白井厚太郎准教授 (東京大学・大 気海洋研究所), 松村清隆博士 (北里大学), 井口亮博士 (産業技 術総合研究所), 仲岡雅裕教授 (北海道大学・厚岸臨海実験所), 池田実教授（東北大学・女川フィールドセンター）を始め, 関係 者の皆様に厚く御礼申し上げます。 2011 年 3 月 11 日に発生した 東日本大震災の被災地にあり, 前所属研究室である東北大学・女 川フィールドセンター（池田 2012，2017）をはじめ，被災地の 復興を心から願っています．本研究の一部は科研費（20K15576） 
の助成により行われました。

\section{引用文献}

Adams DK, Arellano SM, Govenar B 2012. Larval dispersal: vent life in the water column. Oceanography 25: 256-268.

Al-Yahya H, Chen HN, Chan BKK, Kado R, Høeg JT 2016. Morphology of cyprid attachment organs compared across disparate barnacle taxa: does it relate to habitat? The Biological Bulletin 231: 120-129.

Bachraty C, Legendre P, Desbruyeres D 2009. Biogeographic relationships among deep-sea hydrothermal vent faunas at global scale. Deep Sea Research Part I: Oceanographic Research Papers 56; 1371-1378.

Baker ET, Resing JA, Haymon RM, Tunnicliffe V, Lavelle JW, Martinez F, Ferrini V, Walker S, et al 2016. How many vent fields? New estimates of vent field populations on ocean ridges from precise mapping of hydrothermal discharge locations. Earth and Planetary Science Letters 449: 186-196.

Beaulieu SE, Baker ET, German CR 2015. Where are the undiscovered hydrothermal vents on oceanic spreading ridges? Deep Sea Research Part II: Topical Studies in Oceanography 121: 202-212.

Bergquist DC, Eckner JT, Urcuyo IA, Cordes EE, Hourdez S, Macko SA, Fisher CR 2007. Using stable isotopes and quantitative community characteristics to determine a local hydrothermal vent food web. Marine Ecology Progress Series 330: 49-65.

Bielecki J, Chan BKK, Hoeg JT, Sari A 2009. Antennular sensory organs in cyprids of balanomorphan cirripedes: standardizing terminology using Megabalanus rosa. Biofouling 25: 203-214.

Blomsterberg M, Høeg JT, Jeffries WB, Lagersson NC 2004. Antennulary sensory organs in cyprids of Octolasmis and Lepas (Crustacea: Thecostraca: Cirripedia: Thoracica): a scanning electron microscopic study. Journal of Morphology 260: 141-153.

Boschen RE, Rowden AA, Clark MR, Gardner JP 2013. Mining of deepsea seafloor massive sulfides: a review of the deposits, their benthic communities, impacts from mining, regulatory frameworks and management strategies. Ocean \& Coastal Management 84: 54-67.

Brickner I, Høeg JT 2010. Antennular specialization in cyprids of coralassociated barnacles. Journal of Experimental Marine Biology and Ecology 392: 115-124.

Brunner FS, Deere JA, Egas M, Eizaguirre C, Raeymaekers, JA 2019. The diversity of eco-evolutionary dynamics: Comparing the feedbacks between ecology and evolution across scales. Functional Ecology 33: 7-12.

Chan BKK 2003. Studies on Tetraclita squamosa and Tetraclita japonica (Cirripedia: Thoracica) II: larval morphology and development. Journal of Crustacean Biology 23: 522-547.

Chan BKK, Chang YW 2018. A new deep-sea scalpelliform barnacle, Vulcanolepas buckeridgei sp. nov. (Eolepadidae: Neolepadinae) from hydrothermal vents in the Lau Basin. Zootaxa 4407: 117-129.

Chan BKK, Ju SJ, Kim SJ 2019. A new species of hydrothermal vent stalked barnacle Vulcanolepas (Scalpelliforms: Eolepadidae) from the North Fiji Basin, Southwestern Pacific Ocean. Zootaxa 4563: 135148.

Chen HN, Høeg JT, Chan BKK 2013. Morphometric and molecular identification of individual barnacle cyprids from wild plankton: an approach to detecting fouling and invasive barnacle species. Biofouling 29: 133-145.

Chevaldonné P, Fisher CR, Childress JJ, Desbruyères D, Jollivet D, Zal F, Toulmond A 2000. Thermotolerance and the 'Pompeii worms'. Marine Ecology Progress Series 208: 293-295.

Clare AS 2010. Toward a characterization of the chemical cue to barnacle gregariousness. In: Chemical Communication in Crustaceans, Breithaupt T, Thiel M (eds.), Springer, New York, pp. 431-450.

Collins PC, Kennedy R, Van Dover CL 2012. A biological survey meth- od applied to seafloor massive sulphides (SMS) with contagiously distributed hydrothermal-vent fauna. Marine Ecology Progress Series 452: 89-107.

Corliss JB, Dymond J, Gordon LI, Edmond JM, von Herzen RP, Ballard RD, Green K, Williams D, Bainbridge A, Crane K, van Andel TH 1979. Submarine thermal springs on the Galapagos Rift. Science 203: 1073-1083.

Dreanno C, Kirby RR, Clare AS 2007. Involvement of the barnacle settlement-inducing protein complex (SIPC) in species recognition at settlement. Journal of Experimental Marine Biology and Ecology 351: 276-282.

Flight PA, Rand DM 2012. Genetic variation in the acorn barnacle from allozymes to population genomics. Integrative \& Comparative Biology 52: 418-429.

Gale AS, Little CT, Johnson JE, Giosan L 2020. A new neolepadid cirripede from a Pleistocene cold seep, Krishna-Godavari Basin, offshore India. Acta Palaeontologica Polonica 65.

Garlapati D, Charankumar B, Ramu K, Madeswaran P, Murthy MR 2019. A review on the applications and recent advances in environmental DNA (eDNA) metagenomics. Reviews in Environmental Science and Bio/Technology 18: 389-411.

Glynn PW 1965. Community composition, structure, and interrelationships in the marine intertidal Endocladia muricata-Balanus glandula association in Monterey Bay, California. Beaufortia 12: 1-198.

Goodwin S, McPherson JD, McCombie WR. 2016. Coming of age: ten years of next-generation sequencing technologies. Nature Reviews Genetics 17: 333-351.

Hendry AP 2019. A critique for eco-evolutionary dynamics. Functional Ecology 33: 84-94.

Holm ER, Bourget E 1994. Selection and population genetic structure. Marine Ecology Progress Series 113: 247-256.

Husson B, Sarradin PM, Zeppilli D, Sarrazin J 2017. Picturing thermal niches and biomass of hydrothermal vent species. Deep Sea Research Part II: Topical Studies in Oceanography 137: 6-25.

井口 亮・水山 克・頼末武史・藤田喜久 2019. 遺伝子解析によ る琉球列島の海底洞窟性生物群集の多様性と集団形成・維持機 構に関する研究の現状と今後の課題. タクサ：日本動物分類学 会誌 46: 28-33.

池田 実 2012. 女川フィールドセンターにおける被災状況（特別 報告)。複合生態フィールド教育研究センター報告 27: 67-71.

池田 実 2017. 東北大学女川フィールドセンターの復興. 日本水 産学会誌 83: 245-248.

Jollivet D, Chevaldonné P, Planque B 1999. Hydrothermal-vent alvinellid polychaete dispersal in the eastern Pacific. 2. A metapopulation model based on habitat shifts. Evolution 53: 1128-1142.

Jones DO, Amon DJ, Chapman AS 2018. Mining deep-ocean mineral deposits: what are the ecological risks? Elements: An International Magazine of Mineralogy, Geochemistry, and Petrology 14: 325-330.

Koito T, Saitou S, Nagasaki T, Yamagami S, Yamanaka T, Okamura K, Inoue $\mathrm{K} 2018$. Taurine-related compounds and other free amino acids in deep-sea hydrothermal vent and non-vent invertebrates. Marine Biology 165: 183.

Kojima S 2002. Deep-sea chemoautosynthesis-based communities in the Northwestern Pacific. Journal of Oceanography 58: 343-363.

小島茂明 - 渡部裕美 - 藤倉克則 2009. 化学合成生物群集の進化生 態に基づく熱水活動史の推定. 地学雑誌 118: 1174-1185.

Lagersson N, Høeg JT 2002. Settlement behavior and antennulary biomechanics in cypris larvae of Balanus amphitrite (Crustacea: Thecostraca: Cirripedia). Marine Biology 141: 513-526.

Linse K, Jackson JA, Fitzcharles E, Sands CJ, Buckeridge JS. 2013. Phylogenetic position of Antarctic scalpelliformes (crustacea: cirripedia: thoracica). Deep Sea Research Part I: Oceanographic Research Papers 73: 99-116. 
Little CT, Vrijenhoek RC 2003. Are hydrothermal vent animals living fossils? Trends in Ecology \& Evolution 18: 582-588.

Lelièvre Y, Sarrazin J, Marticorena J, Schaal G, Day T, Legendre P, Stephane H, Matabos, M 2018. Biodiversity and trophic ecology of hydrothermal vent fauna associated with tubeworm assemblages on the Juan de Fuca Ridge. Biogeosciences 15: 2629-2647.

Levin LA, Mengerink K, Gjerde KM, Rowden AA, Van Dover CL, Clark MR, Ramirez-Llodra E, Currie B, et al 2016. Defining "serious harm" to the marine environment in the context of deep-seabed mining. Marine Policy 74: 245-259.

Lohse DP 1993. The importance of secondary substratum in a rocky intertidal community. Journal of Experimental Marine Biology and Ecology 166: 1-17.

Lorion J, Kiel S, Faure B, Kawato M, Ho SY, Marshall B, Tsuchida S, Miyazaki J, et al 2013. Adaptive radiation of chemosymbiotic deepsea mussels. Proceedings of the Royal Society B: Biological Sciences 280: 20131243.

Marsh L, Copley JT, Huvenne VA, Linse K, Reid WD, Rogers AD, Sweeting CJ, Tyler PA 2012. Microdistribution of faunal assemblages at deep-sea hydrothermal vents in the Southern Ocean. PLoS One 7: e48348.

Maruzzo D, Conlan S, Aldred N, Clare AS, Høeg JT 2011. Video observation of surface exploration in cyprids of Balanus amphitrite: the movements of antennular sensory setae. Biofouling 27: 225-239.

松村清隆 2014. フジツボ群居への幼生視覚の関与-基板表面の色 を制御することで付着を抑制することは可能か？ マリンエン ジニアリング 49: 508-511.

松村清隆 2006. キプリス幼生の付着機構 1. 日本付着生物学会 (編), フジツボ類の最新学, 恒星社厚生閣, 東京, pp. 142-167.

Matsumura K, Nagano M, Fusetani N 1998. Purification of a larval settlement - inducing protein complex (SIPC) of the barnacle, Balanus amphitrite. Journal of Experimental Zoology 281: 12-20.

松村清隆・野方靖行 2006. 熱水噴出域に生息する蔓脚類の着生に 関する研究. Jamstec Cruise Report. R/V Natsushima/ROV Hyper Dolphin NT06-23, pp. 94-98.

Matsumura K, Qian PY 2014. Larval vision contributes to gregarious settlement in barnacles: adult red fluorescence as a possible visual signal. Journal of Experimental Biology 217: 743-750.

松村清隆・山下桂司・神谷享子・岡田佳子・柳川敏治・岡 洋 祐・川端豊喜 2002. タテジマフジッボおよびアカフジッボキプ リス幼生の着生における着生誘起タンパク質と付着基盤性状の 重要性. Sessile Organisms 19: 93-99.

Mitarai S, Watanabe H, Nakajima Y, Shchepetkin AF, McWilliams JC 2016. Quantifying dispersal from hydrothermal vent fields in the western Pacific Ocean. Proceedings of the National Academy of Sciences 113: 2976-2981.

Miyake H, Kitada M, Tsuchida S, Okuyama Y, Nakamura KI 2007. Ecological aspects of hydrothermal vent animals in captivity at atmospheric pressure. Marine Ecology 28: 86-92.

Moyse J, Høeg JT, Jensen PG, Al-yahya HAH 1995. Attachment organs in cypris larvae: using scanning electron microscopy. In: New Frontiers in Barnacle Evolution. Crustacean Issues 10, Schram FR (ed.), Balkema, Rotterdam, pp. 153-177.

Mullineaux LS 2014. Deep-sea hydrothermal vent communities. In: $M a-$ rine Community Ecology and Conservation, Bartness M., Bruno M, Silliman B \& Stachowicz J. (eds.)., Sinauer, Sunderland, Massachusetts, pp. 383-400.

Mullineaux LS, Metaxas A, Beaulieu SE, Bright M, Gollner S, Grupe BM, Herrera S, Kellner J, et al. 2018. Exploring the ecology of deepsea hydrothermal vents in a metacommunity framework. Frontiers in Marine Science 5: 49 .

Nakajima Y, Shinzato C, Khalturina M, Watanabe H, Inagaki F, Satoh N, Mitarai S 2014. Cross-species, amplifiable microsatellite markers for neoverrucid barnacles from deep-sea hydrothermal vents developed using next-generation sequencing. International Journal of Molecular Sciences 15: 14364-14371.

Newman WA, Yamaguchi T, Southward AJ, Segonzac M 2006. Arthropoda, Crustacea, Cirripedia. Denisia 18: 359-368.

Pérez-Losada M, Harp M, Høeg JT, Achituv Y, Jones D, Watanabe H, Crandall KA 2008. The tempo and mode of barnacle evolution. Molecular Phylogenetics and Evolution 46: 328-346.

Plouviez S, Schultz TF, McGinnis G, Minshall H, Rudder M, Van Dover CL 2013. Genetic diversity of hydrothermal-vent barnacles in Manus Basin. Deep Sea Research Part I: Oceanographic Research Papers 82: 73-79.

Portail M, Olu K, Dubois SF, Escobar-Briones E, Gelinas Y, Menot L, Sarrazin J 2016. Food-web complexity in Guaymas Basin hydrothermal vents and cold seeps. PloS One 11: e0162263.

Ren XQ, Sha ZL 2015. Probathylepadidae, a new family of Scalpelliformes (Thoracica: Cirripedia: Crustacea), for Probathylepas faxian gen. nov., sp. nov., from a hydrothermal vent in the Okinawa Trough. Zootaxa 4033: 144-150.

Ravaux J, Léger N, Hamel G, Shillito B 2019. Assessing a species thermal tolerance through a multiparameter approach: the case study of the deep-sea hydrothermal vent shrimp Rimicaris exoculata. Cell Stress and Chaperones 24: 647-659.

Rogers AD, Tyler PA, Connelly DP, Copley JT, James R, Larter RD, Linse K, Mills RA, et al 2012. The discovery of new deep-sea hydrothermal vent communities in the Southern Ocean and implications for biogeography. PLoS Biology 10: e1001234.

Roterman CN, Copley JT, Linse KT, Tyler PA. Rogers AD 2016. Connectivity in the cold: the comparative population genetics of ventendemic fauna in the Scotia Sea, Southern Ocean. Molecular Ecology 25: 1073-1088.

Schmidt PS, Bertness MD, Rand DM 2000. Environmental heterogeneity and balancing selection in the acorn barnacle Semibalanus balanoides. Proceedings of the Royal Society of London. Series B: Biological Sciences 267: 379-384.

Schmidt PS, Rand DM 1999. Intertidal microhabitat and selection at Mpi: interlocus contrasts in the northern acorn barnacle, Semibalanus balanoides. Evolution 53: 135-146.

Skovmand LH, Xu CC, Servedio MR, Nosil P, Barrett RD, Hendry AP 2018. Keystone genes. Trends in Ecology \& Evolution 33: 689-700.

Smith AB, Stockley B 2005. The geological history of deep-sea colonization by echinoids: roles of surface productivity and deep-water ventilation. Proceedings of the Royal Society B: Biological Sciences 272: 865-869.

Strugnell JM, Rogers AD, Prodöhl PA, Collins MA, Allcock AL 2008. The thermohaline expressway: the Southern Ocean as a centre of origin for deep-sea octopuses. Cladistics 24: 853-860.

Teixeira S, Olu K, Decker C, Cunha RL, Fuchs S, Hourdez S, Serrão EA, Arnaud-Haond, S 2013. High connectivity across the fragmented chemosynthetic ecosystems of the deep Atlantic Equatorial Belt: efficient dispersal mechanisms or questionable endemism? Molecular Ecology 22: 4663-4680.

Toju H, Yamamichi M, Guimarães PR, Olesen JM, Mougi A, Yoshida T, Thompson JN 2017. Species-rich networks and eco-evolutionary synthesis at the metacommunity level. Nature Ecology \& Evolution 1: 1-11.

土田真二・山口寿之・駒井智幸 ・渡部浩美 2008. 節足動物門. 藤 倉克則・奥谷喬司・丸山 正 (編), 潜水調査船が観た深海生 物一深海生物研究の現在. 東海大学出版会, 東京, pp. 178-200.

Tunnicliffe V, Southward AJ 2004. Growth and breeding of a primitive stalked barnacle Leucolepas longa (Cirripedia: Scalpellomorpha: Eolepadidae: Neolepadinae) inhabiting a volcanic seamount off Papua New Guinea. Journal of the Marine Biological Association of the 
United Kingdom 84: 121-132.

Van Dover C 2000. The Ecology of Deep-sea Hydrothermal Vents. Princeton University Press, Princeton, NJ, 412 pp.

Van Dover CL 2014. Impacts of anthropogenic disturbances at deep-sea hydrothermal vent ecosystems: a review. Marine Environmental Research 102: 59-72.

Van Dover CL, Arnaud-Haond S, Gianni M, Helmreich S, Huber JA, Jaeckel AL, Metaxas A, Pendleton LH 2018. Scientific rationale and international obligations for protection of active hydrothermal vent ecosystems from deep-sea mining. Marine Policy 90: 20-28.

Véliz D, Bourget E, Bernatchez L 2004. Regional variation in the spatial scale of selection at MPI* and GPI* in the acorn barnacle Semibalanus balanoides (Crustacea). Journal of Evolutionary Biology 17: 953-966.

Vrijenhoek RC 1997. Gene flow and genetic diversity in naturally fragmented metapopulations of deep-sea hydrothermal vent animals. Journal of Heredity 88: 285-293.

Vrijenhoek RC 2010. Genetic diversity and connectivity of deep-sea hydrothermal vent metapopulations. Molecular Ecology 19: 4391-4411.

Wachi N, Matsubayashi KW, Maeto K 2018. Application of next-generation sequencing to the study of non-model insects. Entomological Science 21: 3-11.

渡部裕美 2003. 西太平洋の化学合成生物群集における分散と進 化. 日本ベントス学会誌 58: 44-49.

渡部裕美 - 加戸隆介 2005. 化学合成生物群集構成者の浮遊幼生 (甲殼類). 日本プランクトン学会報 522: 119-122.

Watanabe H, Kado R, Kaida M, Tsuchida S, Kojima S 2006. Dispersal of vent-barnacle (genus Neoverruca) in the Western Pacific. Cahiers de Biologie Marine 47: 353-357.

Watanabe H, Kado R, Tsuchida S, Miyake H, Kyo M, Kojima S 2004. Larval development and intermoult period of the hydrothermal vent barnacle Neoverruca sp. Journal of the Marine Biological Association of the United Kingdom 84: 743-745.

渡部裕美 - 小島茂明 2009. 熱水噴出域固有動物群の分散と種分 化. 西田 睦 (編), 海洋生命系のダイナミクスシリーズ第 1 巻「海洋の生命史一生命は海洋でどう進化したか」, 東海大学 出版会, 神奈川, pp. 244-260.

Watanabe H, Tsuchida S, Fujikura K, Yamamoto H, Inagaki F, Kyo M, Kojima S 2005. Population history associated with hydrothermal vent activity inferred from genetic structure of neoverrucid barnacles around Japan. Marine Ecology Progress Series 288: 233-240.

Watanabe HK, Chen C, Marie DP, Takai K, Fujikura K, Chan BKK 2018. Phylogeography of hydrothermal vent stalked barnacles: a new species fills a gap in the Indian Ocean 'dispersal corridor' hypothesis. Royal Society Open Science 5: 172408.

Whitham TG, Bailey JK, Schweitzer JA, Shuster SM, Bangert RK, LeRoy CJ, Lonsdorf EV, Allan GJ, et al. 2006. A framework for commu- nity and ecosystem genetics: from genes to ecosystems. Nature Reviews Genetics 7: 510-523.

Xu T, Sun J, Lv J, Watanabe HK, Li T, Zou W, Rouse GW, Wang S, et al. 2017. Genome-wide discovery of single nucleotide polymorphisms (SNPs) and single nucleotide variants ( $\mathrm{SNVs}$ ) in deep-sea mussels: Potential use in population genomics and cross-species application. Deep Sea Research Part II: Topical Studies in Oceanography 137: 318-326.

矢萩拓也・Chen Chong・川口慎介 2019. 深海の化学合成生態系 動物群集の幼生分散過程. 海の研究 28: 97-125.

Yahagi T, Kayama Watanabe H, Kojima S, Kano, Y 2017. Do larvae from deep-sea hydrothermal vents disperse in surface waters? Ecology 98: 1524-1534.

Yamaguchi T 1997. The hydrothermal vent barnacle Eochionelasmus (Cirripedia, Balanomorpha) from the North Fiji, Lau and Manus Basins, South-West Pacific. Zoosystema 19: 623-649.

山口寿之 2006. 熱水噴出孔に棲む原初的なフジツボ類. 日本付着 生物学会 (編), フジッボ類の最新学, 恒星社厚生閣, 東京, pp. 29-40.

Yorisue T 2018. Diverse larval dispersal and settlement strategies in thoracican barnacles. In: Barnacles: Recent Progress in Biology and Antifouling, Kado R, Mimura H, Endo N (eds.), Nova Science Publishers, New York, pp. 49-68.

Yorisue T, Chan BKK, Kado R, Watanabe H, Inoue K, Kojima S, Høeg JT 2016. On the morphology of antennular sensory and attachment organs in cypris larvae of the deep-sea vent/seep barnacles, Ashinkailepas and Neoverruca. Journal of Morphology 277: 594-602.

Yorisue T, Inoue K, Miyake H, Kojima S 2012. Trophic structure of hydrothermal vent communities at Myojin Knoll and Nikko Seamount in the northwestern Pacific: Implications for photosynthesis-derived food supply. Plankton and Benthos Research 7: 35-40.

Yorisue T, Kado R, Watanabe H, Høeg JT, Inoue K, Kojima S, Chan BKK 2013. Influence of water temperature on the larval development of Neoverruca sp. and Ashinkailepas seepiophila - Implications for larval dispersal and settlement in the vent and seep environments. Deep Sea Research Part I: Oceanographic Research Papers 71: 33-37.

Yorisue T, Matsumura K, Hirota H, Dohmae N, Kojima S 2012. Possible molecular mechanisms of species recognition by barnacle larvae inferred from multi-specific sequencing analysis of proteinaceous settlement-inducing pheromone. Biofouling 28: 605-611.

頼末武史・渡部裕美 2010. 深海化学合成生物群集の幼生分散. 生 物の科学遺伝 64: 55-59.

Yu MC, Dreyer N, Kolbasov GA, Høeg JT, Chan BKK 2020. Sponge symbiosis is facilitated by adaptive evolution of larval sensory and attachment structures in barnacles. Proceedings of the Royal Society $B$ 287: 20200300 . 